\author{
Anna De Ambrosis Vigna \\ Uniwersytet w Białymstoku \\ a.budnik@uwb.edu.pl \\ ORCID ID: https://orcid.org/0000-0002-2892-6900

\section{Dariusz R. Kijowski} \\ Uniwersytet w Białymstoku \\ kijowski@uwb.edu.pl \\ ORCID ID: https://orcid.org/0000-0003-4236-2977
}

\title{
The Principle of Legitimate Expectations and the Protection of Trust in the Polish Administrative Law
}

\begin{abstract}
The principle of legitimate expectations concerns primarily the relationship between public administration and individuals. It endeavours to solve the conflict between the administration's goal to protect confidence in its activities and the need for change of the objectives of administrative policy. In the Polish administrative law, the concept of legitimate expectations has so far been identified with the principle of the protection of trust. The aim of this study is to demonstrate that the recent amendment to the Polish Code of Administrative Procedure should serve as an impulse for further research into the meaning of this principle in the domestic legal order.
\end{abstract}

Keywords: legitimate expectations, protection of trust, public administration, EU law, Polish law

\section{Introduction}

The principle of legitimate expectations concerns primarily the relationship between public administration and individuals. It endeavours to solve the conflict between the administration's goal to protect confidence in its activities and the need for change of the objectives of administrative policy. It might seem that the claim that the role of administrative law is to protect legitimate expectations of the individual should not raise any controversies. Only a consistent public administration which breaks its prior promises solely in justified cases can create a sense of justice and citizens' trust. 
In the Polish administrative law, the concept of legitimate expectations has so far been identified with the principle of the protection of trust. The aim of this study is to demonstrate that the recent amendment to the Code of Administrative Procedure ${ }^{1}$ (CAP), particularly its art. 8, should serve as an impulse for further research into the meaning of this principle in the domestic legal order. The study is based on the analysis of the European and Polish jurisdictions and of relevant literature.

\section{The principle of legitimate expectations in European Union law}

Protection of legitimate expectations originates in the German principle of Vertrauensshutz which means protection of trust and is directly related to the protection of the acquired rights ${ }^{2}$. The origin of the principle can be traced back to judgments concerning the withdrawal of unlawful administrative acts conferring benefits. In the judgments of the 1950's and 1960's a principle was looked for, which could relativise the principle of legality of the administration as a subprinciple of the rule of law. "The first judgments mentioned the principles of good faith and legal certainty as the source for the protection of legitimate expectations. Meanwhile the principle of legitimate expectations is established as an autonomous manifestation

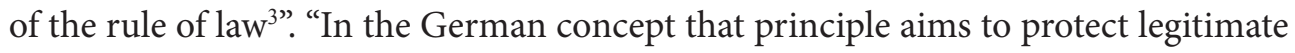
dispositions of individuals from changing assessments of the legal situation (administration) and changes in the legal framework (legislature). The principle does not protect from any disappointment; only those expectations are regarded legitimate which have led to relevant dispositions. The principle can be activated in combination with fundamental rights versus the executive branch or the legislature."

The principle of the protection of legitimate expectations was later adopted by EU law as a result of the judicial activities of the European Court of Justice (now Court of Justice of the European Union - CJEU).

In the early stages of the development of the rules governing proceeding before EU administrative bodies, the principles contained in domestic legal acts, common law and those established through court decisions, which were sometimes reflected in the positive law, were used. The jurisdiction of the CJEU which has formulated many general principles of EU law is considered part of the primary legislation of the EU. Among other sources these principles are derived from constitutional

1 Act of 14 June 1960 (consolidated text Journal of Laws 2017, item 1257).

2 J. Lemańska, Uzasadnione oczekiwana w perspektywie prawa krajowego i regulacji europejskich, Warszawa 2016, p. 35.

3 The Protection of Legitimate Expectations in Administrative Law and EU Law. Answers to Questionnaire: Germany, Seminar organized by the Supreme Administrative Court of Lithuania and ACA-Europe, Vilnius, 21-22 April 2016. Ibidem. 
The Principle of Legitimate Expectations and the Protection of Trust...

traditions shared by the member states as well as from international agreements, including the European Human Rights Convention. General principles of EU law are of constitutional nature and are binding for the member states ${ }^{5}$. General principles are principles of public law because they concern relations between individuals and EU administration or a member state ${ }^{6}$. The CJEU analyses the validity of a contested community act not merely based on relevant clear provisions of the Treaty and their interpretation included in the existing jurisdiction but also in light of "basic principles", which it itself has formulated, drawing on legal traditions of different member states ${ }^{7}$.

The development of rules which govern EU law was largely influenced by its adoption of the European Convention of Human Rights.

The EU principles of human rights were included in the Charter of Fundamental Rights of the European Union (charter), which was adopted in Nice on December 7, 2000. This document became legally binding under the Lisbon treaty and now forms part of the primary EU law. What is relevant for our study is the right to good administration expressed in art. 41 of the charter. This right, stresses that individual cases should be investigated by the EU bodies and institutions impartially, fairly and within a reasonable timeframe. The administrative actions should be clear, intelligible and transparent. In the spirit of this requirement, every individual is ensured the right to access relevant documents and the right to express his or her opinion on the case before the verdict is given and administrative organs are obliged to justify their decisions. $^{8}$

The principles which form the right to good administration were later developed in the European Code of Good Administrative Behaviour (Code). The Code is an important instrument which enables the implementation of good administration principles in the EU institutions. It helps citizens understand their rights and monitor their observance. Moreover, it increases the level of societal interest in an open, effective and independent European administration ${ }^{9}$.

5 A. Krawczyk, Zasady postępowania przed organami administracji unijnej, (in:) System prawa administracyjnego. Europeizacja prawa administracyjnego, R. Hauser, Z. Niewiadomski, A. Wróbel (eds.), t. 3, Warszawa 2014, pp. 208-209.

$6 \quad$ Ibidem, p. 209.

7 E. Sharpston, European Community Law and the Doctrine of Legitimate Expectations: How Legitimate, and for Whom, "Northwestern Journal of International Law \& Business" 1990, vol. 11, issue 1, p. 89.

8 H. Babiuch, Europejski Kodeks Dobrej Administracji a polska procedura i praktyka administracyjna, "Zeszyty Naukowe Państwowej Wyższej Szkoły Zawodowej im. Witelona w Legnicy" 2017, no.1, p. 6.

9 Europejski kodeks dobrej praktyki administracyjnej, Europejski Rzecznik Praw Obywatelskich, p. 4, https://www.ombudsman.europa.eu/en/resources/code.faces/pl/3510/html.bookmark\#/ page/1 (access 8.12.2017). 
The principle of legitimate expectations has been expressed in art. 10 of this document. The article says that: "The official shall be consistent in his own administrative behaviour as well as with the administrative action of the Institution. The official shall follow the Institution's normal administrative practices, unless there are legitimate grounds for departing from those practices in an individual case; these grounds shall be recorded in writing." Paragraph 2 of this article goes on to say: "The official shall respect the legitimate and reasonable expectations that members of the public have in the light of how the Institution has acted in the past."

The legitimate expectations principle was thus first expressed in normative terms in the European Code of Good Administrative Behaviour. Polish commentaries to this regulation describe it as the principle of the protection of trust which among other things implies predictability of decisions which is phrased as "legitimate expectations, consistent action and legal counselling"10.

As mentioned above, in EU law, the principle of legitimate expectations was formed in the process of the judiciary activity of the CJEU. "The European Court did not establish the theoretical bases of the principle but in its decisions, it often indicated why it should be used. Among other things, it stated that this principle has a specific equitable function which ensured fair dealing and good faith as minimum standards of Community administration. It would be unfair for the administration to raise certain expectations as to its further conduct which are then subsequently disappointed, without good reason." ${ }^{11}$

The principle allows the European Court to strike a balance between justice and the legal rigor. In one of the investigated cases the Advocate General declared that the doctrine of legitimate expectations is "undeniably part of Community law"12.

The European Court of Justice recognised that the principle of legitimate expectations originates from the principle of legal certainty ${ }^{13}$. The working of the principle of legal certainty means that violation of legitimate expectations is seen as violation of "the primary rule of law and order" 14 .

In EU law the principle of legitimate expectations is primarily called for in cases which concern the agricultural market and industry. This seems understandable from the economic perspective. According to E. Sharpston "The general rule appears to be that the European Court will usually be prepared to back the Council

10 J. Świątkiewicz, Europejski Kodeks Dobrej Administracji (wprowadzenie, tekst i komentarz o zastosowaniu kodeksu w warunkach polskich procedur administracyjnych), Warszawa, March 2007, p. 27.

11 R. Thomas, Legitimate expectation and proportionality, Oxford-Portland Oregon 2000, p. 44.

12 Judgment of CJEU of 19 September 1985 on the joint cases Finsider v. commission, C-63 and $147 / 84$.

13 Judgment of CJEU of 15 February 1996 on the case Duff and others v. Minister for Agriculture and Food, Ireland, and the Attorney General, C-63/93.

14 Judgment of CJEU of 14 May 1975 on the case CNTA SA v. Commission, C-74/74, p. 549. 
The Principle of Legitimate Expectations and the Protection of Trust...

and/or Commission and to hold that they are entitled to have a fairly wide margin of maneuver in market management, even where the chosen scheme has been subjected to fairly heavy criticism. This ties in with the basic principle essential, it is suggested, to a rational attempt at market management by the public authorities - that those authorities should be free to legislate (and to modify legislation) in the general economic interest, in the light of what they perceive to be the requirements of a changing overall economic situation." ${ }^{15}$ In one of its decisions the European Court stated that "Every entrepreneur in which an administrative body raises legitimate hopes may appeal to the principle of legitimate expectations. On the other hand, if a reasonable entrepreneur subject to other treatment could have foreseen the adoption of a communal measure which could affect his interests, he or she cannot appeal to this principle if the measure has been adopted." 16 The European Court purports however that the discretionary power is not unlimited. For example, it can be seen in the decision on Mulder v. Minister van Landbouw en Visseri ${ }^{17}$, concerning milk producers who entered into a joint programme through which for five years they received compensation for suspending their milk production and trade. Toward the end of that period the producers made investments to reactivate their production. In the meantime, another scheme, so called super-levy, came into force but producers who had joined the earlier one could not benefit from it because they did not meet the necessary requirement of a given quantity of milk produced in the referential period. For this reason their applications were rejected. The European Court decreed that the resolution was illegal because it violated the principle of legitimate expectations. A producer who suspended his production of milk cannot expect that he would not be subject to market or structural policy which is adopted in the meantime. The Court adjudged that a producer encouraged by a communal scheme to suspend his milk production for a given period has the right to expect that he/she would not be subject to restrictions for the exclusive reason of benefiting from communal regulations. Producers could not have foreseen that they would be excluded from the common market $^{18}$.

In line with the European court jurisdiction, three conditions must be satisfied to justify a claim for entitlement to the protection of legitimate expectations. First, precise, unconditional and consistent assurances originating from authorised and reliable sources must have been given to the person concerned by the Community authorities. Second, those assurances must be such as to give rise to a legitimate

15 E. Sharpston, European Community Law..., op. cit., p. 90.

16 Judgment of the Court of 11 March 1987, Van den Bergh en Jurgens BV i Van Dik Food Products (Lopik) BV v. Commission, C-265/85.

17 Judgment of the Court of 28 April 1988, Mulder v. Minister van Landbouw en Visserij, C-120/86.

18 A. Jurcewicz, Traktatowe podstawy unijnego prawa rolnego w świetle orzecznictwa, Warszawa 2012, pp. 129-130. 
expectation on the part of the person to whom they are addressed. Third, the assurances given must comply with the applicable rules ${ }^{19}$.

In seeking justification for respecting the protection of legitimate expectations the doctrine of many European states appeals to the reliance theory and the rule of law theory. The former means that "legitimate expectations should be protected because to do otherwise would inflict harm on individuals who rely upon such expectation $\mathrm{s}^{20}$. A public authority's freedom to take action in the public interest is limited to the extent that it causes harm to particular individuals. If a public authority has induced a person to rely upon its representations or conduct, realising that such reliance was a real possibility, it is under a prima facie duty to act in a such way that the reliance will not be detrimental to the representee ${ }^{21}$. The rule of law as a source of legitimate expectations means that for individuals to be autonomous they must at least, be able to plan ahead and therefore foresee with some degree of certainty the consequences of their actions ${ }^{22}$. "Economic activity, which is an important aspect of autonomous decision-making, can only be carried out if economic operators 'can rely on something" ${ }^{23}$. In a dynamically changing and uncertain world this right is something they should be allowed to and largely rely on. It is emphasised that in administrative law certainty is particularly important in cases of discretionary administrative actions. The principle of the rule of law in administrative law means that protection and respect for expectations makes the discretionary action of administrative bodies more predictable. The principle of the rule of law establishes therefore legal certainty and predictability ${ }^{24}$.

As concerns the relation between the European and domestic law the CJEU adjudged that the principles of legitimate expectations and legal certainty are part of the legal order of the Community. The fact that domestic legislation provides for the same principles which are to be applied in cases like return of unlawfully issued communal subsidy cannot thus be regarded as in conflict with the same legal order. Moreover, as investigation of domestic provisions of the member states regarding the annulment of administrative decisions and repayment of financial benefits which were unlawfully issued by public authorities clearly shows the worry of achieving balance between the principle of legality on the one hand and the principles of legal certainty and protection of legitimate expectations on the other,

19 Judgment of the Court of First Instance (Fifth Chamber) of 30 June 2005, Eugénio Branco v. Commission, T-347/03, \$120.

20 S. Shonberg, Legitimate expectation in administrative law, Oxford 2000, p. 9.

21 Ibidem, p. 10.

22 Judgment of the Court of 14 May 1975 in the case CNTA SA v. Commission, C-74/74, p. 549.

23 S. Shonberg, Legitimate expectation..., op. cit., p. 12.

24 Ibidem, p. 12-13. 
The Principle of Legitimate Expectations and the Protection of Trust...

though in different ways, is commonly expressed in the regulations adopted by the member states ${ }^{25}$.

\section{Protection of legitimate expectations in the Polish law}

The principle of the protection of legitimate expectations (as understood above) has not been explicitly expressed in the Polish law or jurisdiction. It does not mean, however, that it has not been taken note of by representatives of the administrative law doctrine. Thus far it has been customary in the Polish law to regard the principle of the protection of legitimate expectations as corresponding to the principle of citizens' trust in the state and its laws. In the Polish legal tradition, it corresponds to the above mentioned German principle of Vertrauensschutz. The principle is derived from art. 2 of the Constitution of the Republic of Poland and the principle of a democratic rule of law that it expresses.

Z. Kmieciak, shows that values and ideas identified with legitimate expectation, Vertrauensschutz or confiance légitime in the French law are sometimes directly identified with the principle of trust and the principle of legitimately acquired rights ${ }^{26}$. Following J.M. Woehrling he included the following principles in the "foundations" of the principle of the protection of trust: the principle of legal safety and legal certainty, the principle of coherence of public actions, the principle of good faith and the estoppel principle; the principle of impartiality, the principle of respect for fundamental rights and the principle of legitimately acquired rights ${ }^{27}$.

Since it is assumed that the principle of legitimate expectations is to be derived from the principle of trust in the state and its organs, two provisions of the Polish legal order in which it has been expressed deserve special attention. These are the above-mentioned art. 2 of the constitution and art. 8 of the CAP.

The Polish Constitutional Tribunal (CT) has long since noticed that the principle dictating that the proceeding be conducted in a way which raises the trust of its participants in the public authorities, previously called raising citizen's trust in the state and its law, is an element of a democratic state under the rule of law ${ }^{28}$. The CT decreed that this principle is of basic importance for the normative content of the rule of law clause. It arises from the function of this clause which is to determine relations between a person and the state ${ }^{29}$. The primary meaning of the principle

25 Judgement of the Court of 21 September 1983 on the cases Deutsche Milchkontor GmbH et al. v. Germany, C-205/82 and C-215/82.

26 Z. Kmieciak, Ogólne zasady prawa i postępowania administracyjnego, Warszawa 2000, p. 65.

27 Ibidem, p. 70-71.

28 Judgment of the CT of 30 November 1988, K. 1/88, OTK 1988, item 6.

29 P. Tuleja, Komentarz do art. 2 Konstytucji, (in:) Konstytucja RP, tom 1, Komentarz do art. 1-86, M. Safjan, L. Bosek (eds.), Wraszawa 2016, Legalis/el. 
is the need to protect and respect legitimately acquired rights and protect pending interests ${ }^{30}$, but also to prevent the lawmaker from such normative constructs which are impossible to implement, form the illusion of law and as a result are merely a pretence of protection of those property interests which are functionally related to the content of the established substantive right ${ }^{31}$. The CT links the principle of trust primarily with the citizens' trust in the state and its laws. In another ruling the CT stated that the principle of trust relates to legal certainty and "legal certainty is not to mean stability of legal regulations which in this area may be hard to attain in some economic conditions of the state, as much as it refers to predictability of the actions of the state organs and the related conduct of citizens. Predictability of state actions warrants trust in the lawmaker and the laws"32.

In the light of the CT jurisdiction the principle of the protection of citizens' trust in the state and its laws (also known as the principle of state loyalty to its citizens) is addressed to the state authorities and its content could be reduced to the disallowing of the lawmaker to 'set traps' for the citizens, and of the state to make empty promises or suddenly withdraw promises or established rules of conduct. ${ }^{33}$

The principle of the protection of an individual's trust in the state and its laws is closely related with the legal security of the individual ${ }^{34}$. It is expressed in such processes of law creation and law application, "which would prevent it from becoming a sort of trap for the citizens and enable them to organise their affairs trusting that they are not exposing themselves to legal consequences which could not have been foreseen at the time of decision making and activity and convinced that the actions which they undertake in line with the effective law would be acknowledged by the legal order also in the future." 35 The Polish CT also stressed that legal security, predictability of the law made by the state as well as respect of the authorities for actions undertaken with trust in the state, guarantees protection of human liberties ${ }^{36}$. Moreover, the CT concluded in its rulings that the principle of univocality of law as well as unlawfulness of the creation of illusory rights ensue from the principle of trust. "In a democratic state governed by the rule of law, the processes of law creation and law application cannot be a trap for the citizen and the citizen should be able to arrange his or her affairs with trust that he or she does not expose him/herself to

30 Judgment of the CT of 2 March 1993, K 9/92, OTK 1993, no. 1, item. 6.

31 Judgment of the CT of 19 December 2002, K 33/02, OTK-A 2002, no. 7, item 97.

32 Judgment of the CT of 2 March 1993, K. 9/92, OTK 1986-1995 (t. 4), 1993, part I, item 6; judgment of the Constitutional Tribunal of 24 May 1994, K. 1/94, OTK 1994, part I, item 10.

33 Judgment of the CT of 23 July 2013, P 4/11, OTK ZU No. 6/A/2013, item 82, p. 1132; judgment of the CT of 8 April 2014, SK 22/11, OTK ZU No. 4/A/2014, item 37, pp. 562-563.

34 P. Tuleja, Komentarz..., op. cit.

35 Judgment of the CT of 7 February 2001, K 27/00, OTK 2001, No. 2, item 29.

36 P. Tuleja, Komentarz..., op. cit. 
The Principle of Legitimate Expectations and the Protection of Trust...

adverse legal consequences of his/her decisions and actions which are impossible to predict at the time of making the decisions and undertaking the actions" ${ }^{37}$.

According to art. $8 \$ 1$ of the CAP: “The organs of public administration carry out their proceedings in a way that raises the trust of its participants in the public authorities, governed by the principle of proportionality, impartiality and equal treatment". Moreover, in art. $8 \$ 2$ of the CAP, the lawgiver forbade the organs of public administration from abandoning the established decision-making practice when dealing with the same factual and legal situation.

The principle of trust was first formulated in the original version of the CAP but its origins can be traced back to the bill establishing the Supreme Administrative Court and later democratic changes which followed after 1989. It is pointed out that development of this principle should be ascribed to the jurisdiction of the Constitutional Tribunal, the Supreme Administrative Court and regional administrative courts ${ }^{38}$.

The principle of trust is tied up with the principle of the protection of pending interests. It ensures protection of the individual in circumstances where he or she undertook a given venture based on existing regulations. The CT stresses, however, that it does not have an absolute character. This duty is of a more categorical nature, if the lawgiver set a timeframe in which given ventures can be conducted under predetermined rules ${ }^{39}$.

The principle of the protection of trust in the state and its laws is also often appealed to by administrative courts. The Supreme Administrative Court (SAC) ruled that passing of a regulation which allows for its arbitrary interpretation constitutes the breach of the principle of the protection of trust in the state and its laws ${ }^{40}$. The principle of the protection of trust in the state and its laws requires, for example, that the tax payer should know whether his or her tax duty has or has not expired ${ }^{41}$. The Supreme Administrative Court referred to the principle of trust in the matter of judiciary actions. It stated that "In a democratic state governed by the rule of law it is wrong and unacceptable for the same court with a differently composed panel to issue a different ruling based on the same factual and legal situation." 42

37 Judgment of the CT of 25 November 1997, K 26/97, OTK 1997, No. 5-6, item 64.

38 The Protection of Legitimate Expectations in Administrative Law and EU Law. Answers to Questionnaire: Poland, Seminar organized by the Supreme Administrative Court of Lithuania and ACA-Europe, Vilnius, 21-22 April 2016, p. 4.

39 P. Tuleja, Komentarz..., op. cit.

40 Order of the SAC of 21 October 2013, I FSK 2797/11, LEX no. 1378115.

41 Judgment of the SAC of 15 October 2013, I GSK 1543/11, LEX no. 1441241.

42 Judgment of the SAC of 10 October 2013., I FSK 1292/12, LEX no. 1504915. 
The current wording of art. 8 of the CAP is a result of the amendment to the CAP which came into force in June $2017^{43}$. It is thus worthwhile to consider whether this change contributed a new perspective on the principle of the protection of legitimate expectations in the Polish legal system. Among the reasons given for introducing changes to the CAP it was pointed out that the set of the general principles of administrative proceeding included in the earlier code did not fully realize the principles of good administration which the Code expressed along with other sources. One can find statements in the Polish doctrine according to which the Polish administrative proceeding contains the principles included in the Code ${ }^{44}$. Other authors, e.g. A. Zoll, pointed out that Poland still has a long way to go in the task of including the Code in the Polish administrative proceeding ${ }^{45}$.

A closer look at the normalising scope of art. $8 \$ 2$ of the CAP and art. 10 of the Code shows that the Polish legislator did not intend to explicitly state the principle of the protection of legitimate expectations which is mentioned in the art. 10 paragraph 2 of the Code. Art. $8 \$ 2$ of the CAP speaks only of a consistent application of administrative practice in the activities of public administration. We believe this does not exhaust the essence of the principle of the protection of legitimate expectations. According to P. Przybysz, the principle of respect for an established decision-making practice in the same factual and legal situation (art. $8 \$ 2$ ) is an element of the principle of equal treatment ${ }^{46}$.

It seems, however, that there is no need for a normative expression of the principle of the protection of legitimate expectations in the Polish legal system, for it can be derived from the effective legal provisions (the Constitution, the CAP and the tax ordinance).

According to J. Lemańska, legitimate expectations are a theoretical concept which signifies a legally qualified factual interest resulting from a subjective belief of an individual which is considered worthy of legal protection based on objectified circumstances even though it has no explicit basis in the content of a legal norm ${ }^{47}$. She also suggests that the source of the protection of legitimate expectations, which in Poland form a qualified factual interest, is article 7 of the CAP, which states that in

43 Act of 7 April 2017 amending the Act - Code of administrative proceedings and some other acts (Journal of Laws of 2017, item 935).

44 J. Boć, Administracja a obywatel, (in:) A. Błaś, J. Jeżewski, Administracja publiczna, J. Boć (ed.) Poznań 2004, p. 254.

45 A. Zoll, Prawo do dobrej administracji, (in:) Europejski kodeks Dobrej Administracji (tekst i komentarz o zastosowaniu kodeksu w warunkach polskich procedur administracyjnych), J. Świątkiewicz (ed.), Warszawa 2007, p. 5, https://www.rpo.gov.pl/pliki/1192700305.pdf (access 8.12.2017).

46 P. Przybysz, Komentarz do art. 8 Kodeksu postępowania administracyjnego, Lex/el. (access 8.12.2017). 
The Principle of Legitimate Expectations and the Protection of Trust...

their proceedings the public administrative bodies take account of the social interest and legitimate interest of the citizens. The legitimate interest of the citizens is not just their legal interest but also their qualified factual interest, i.e. (legitimate) expectations rightly understood, for the above-mentioned article of the CAP does not say that it is merely concerned with the legal interest ${ }^{48}$. It should be added that from art. 2 of the constitution which appeals to the principle of a democratic state under the rule of law one can derive directives which are relevant not only for the legislator but also for all public organs. And the principle of the protection of legitimate expectations is - as shown above - one of the constitutive elements of the concept of the democratic state under the rule of law.

In the Polish doctrine it had already been pointed out before that art. 10 of the Code alludes to previously adopted precedents which should be understood as established administrative practice. Societal opinion becomes accustomed to a given way of proceeding by the public administration and any deviations in uniform cases cause anxieties and a suspicion of subjectivism, if not abuse, on the part of the organs. If, therefore, there is a change of situation which requires abandoning of the existing practice (e.g. due to budget or financial constraints or a need to consider other priorities) the administrative organ ought to justify this departure ${ }^{49}$.

The principle of the protection of legitimate expectations means that every individual who, as a result of administrative action, formed certain expectations concerning future administrative actions may demand that these expectations are met unless there are compelling reasons of public interest for not allowing this. The CJEU has indicated that from the juridical point of view this principle should be regarded as a kind of a legal expectation concerning the action of an organ which establishes or administers EU law in relation to an individual who cannot appeal to acquired rights ${ }^{50}$.

It is beyond the scope of this short study to point to all rulings which invoke the principle of the protection of trust in the public organs or discuss all aspects of its application. We thus stop short of only a couple of examples. According to courts, an administrative organ must not inform a party of the content of legal regulations or ways to interpret them, nor can it at a later stage - when the party has undertaken action on the basis of acquired information, trusting in its content - undertake actions (issue rulings) which contradict the content of provided information ${ }^{51}$. Imposing sanctions on the party for his or her failing to meet an obligation, which

\footnotetext{
$48 \quad$ Ibidem, p. 80.

49 J. Świątkiewicz, Europejski Kodeks Dobrej Administracji (wprowadzenie, tekst i komentarz o zastosowaniu kodeksu w warunkach polskich procedur administracyjnych) Wydanie VI, Warszawa 2007, pp. 27-28, https://www.rpo.gov.pl/pliki/1192700305.pdf (access 30.11.2017).

50 Ł. Prus, the commentary to the judgment of the CJEU of 19 May 1992 r., C-104/89 oraz C-37/90, "Europejski Przegląd Sądowy" 2012, no. 3, pp. 33-38.

51 Judgment of the SAC of 28 November 1997, SA/Sz 1970/96, LEX no. 32028.
} 
he or she could not have met even in due diligence, may be inconsistent with the principle which requires that the proceeding be conducted in a way that does not diminish the trust of its participants in the public organs ${ }^{52}$. The undertaking of contradictory actions in the same case by the public authorities will not help obey the principle which states that proceeding be conducted in a way that supports trust of its participants in public authorities ${ }^{53}$. A breach of the principle expressed in art. 8 of the CAP is also found in the changeability of legal opinions expressed in decisions issued by administrative organs in relation to the same addressee, based in the same factual situation, indicating the same legal basis for the decision and failing to provide justification for the change ${ }^{54}$. In a different ruling, the SAC stated that a situation in which administrative information leads to a breach of material legal regulations cannot be accepted ${ }^{55}$.

The principle of trust in the actions of public organs in the Polish legal order has a wide scope. It also forms an imperative for the public administration to keep promises and respect the established practices if that serves the public interest. The principle of the protection of legitimate expectations in the Polish law is a standard whose origins can be traced to the principle of law and order as well as the principle of trust in the state and its organs.

\section{Conclusion}

The principle of the protection of legitimate expectations does not hold an autonomous status in the Polish legal system. Fulfilment of the principle of the protection of legitimate expectations in Poland is to serve the process of building trust in public administration organs. It also corresponds with the principles of equality, proportionality, legal certainty and subsidiarity ${ }^{56}$.

What speaks for respecting the principle is the fact that since it is a European principle, it would prevent a situation in which individuals would enjoy broader protection before the EU organs than the scope determined in the regulations of the member states. If legitimate expectations are highly ranked on the EU level, it serves as an argument for providing the right scope of protection in the domestic law ${ }^{57}$. Moreover, Poland as the EU member has obliged itself to respect the standards of the rule of law and it should respect the principles of good administration.

52 Judgment of the Regional Administrative Court in Białystok of 25 July 2007, II SA/Bk 276/07,

53 Judgment of the SAC of 26 November 1999, V SA 978/99, LEX no. 49942.

54 Judgment of the SAC of 8 April 1998, I SA/Łd 652/97, ONSA 1999, no. 1, item 27, http:// orzeczenia.nsa.gov.pl

55 Judgment of the SAC of 24 August 1988, SA/Rz 242/99, http://orzeczenia.nsa.gov.pl

56 P. Przybysz, Komentarz do art. 8..., op. cit.

57 R. Arigho, Legitimate Expectations in Irish and EU law - Lessons for Ireland? "Irish Journal of European Law" 2016, vol. 19, issue 1, pp. 77-78. 
The recent amendment has introduced a new provision to the Polish administrative proceeding by outlawing departures from established decisionmaking practice in a factual and legal situation which undoubtedly expresses the principle of the protection of legitimate expectations of an individual. This does not however exhaust the content of the principle. Moreover, it should be noted that the amendment of the CAP at the same time satisfies recommendations outlined in the draft General Provisions of the Administrative Law. The authors of this bill, in line with the requirements of the right to good administration, called for an explicit inclusion of the principles of proportionality, impartiality and equality in the bill ${ }^{58}$.

It is apparent then that the lawmaker has included in the existing provisions of administrative procedure the missing standards provided for in the European Code of Good Administrative Behaviour. It seems therefore that a separate formulation of the principle of the protection of legitimate expectations in the bill is superfluous. Moreover, as indicated in the above referenced rulings of courts and the Constitutional Tribunal, the content of the principle of trust in state organs in Poland corresponds to the understanding of the protection of legitimate expectations as expressed in the jurisdiction and doctrine of the European states and the EU. One could therefore hope that the principle will be taken note of and applied by Polish administrative organs and courts.

\section{BIBLIOGRAPHY}

Arigho R., Legitimate Expectations in Irish and EU law - Lessons for Ireland? "Irish Journal of European Law” 2016, vol. 19, issue 1 .

Babiuch H., Europejski Kodeks Dobrej Administracji a polska procedura i praktyka administracyjna, Zeszyty Naukowe Państwowej Wyższej Szkoły Zawodowej im. Witelona w Legnicy” 2017, no. 1.

Boć J., Administracja a obywatel, (in:) A. Błaś, J. Jeżewski, Administracja publiczna, J. Boć (ed.) Poznań 2004.

Europejski kodeks dobrej praktyki administracyjnej, Europejski Rzecznik Praw Obywatelskich, https:// www.ombudsman.europa.eu/en/resources/code.faces/pl/3510/html.bookmark\#/page/1 (access 8.12.2017).

Jurcewicz A., Traktatowe podstawy unijnego prawa rolnego w świetle orzecznictwa, Warszawa 2012.

Kmieciak Z., Ogólne zasady prawa i postępowania administracyjnego, Warszawa 2000.

Krawczyk A., Zasady postępowania przed organami administracji unijnej, (in:) System prawa administracyjnego. Europeizacja prawa administracyjnego, R. Hauser, Z. Niewiadomski, A. Wróbel (eds.), t. 3, Warszawa 2014.

58 Although the draft General Provisions of the Administrative Law did not explicitly include these principles, the authors pointed to the possibility of considering the introduction of the Code rules into the Polish regulation in an extended formula than it is determined in the existing Polish regulations. 
Lemańska J., Uzasadnione oczekiwana w perspektywie prawa krajowego i regulacji europejskich, Warszawa 2016.

The Protection of Legitimate Expectations in Administrative Law and EU Law. Answers to Questionnaire: Germany, Seminar organized by the Supreme Administrative Court of Lithuania and ACA-Europe, Vilnius, 21-22 April 2016.

The Protection of Legitimate Expectations in Administrative Law and EU Law. Answers to Questionnaire: Poland, Seminar organized by the Supreme Administrative Court of Lithuania and ACA-Europe, Vilnius, 21-22 April 2016.

Prus Ł., the commentary to the judgment of the CJEU of 19 May 1992 r., C-104/89 oraz C-37/90, "Europejski Przegląd Sądowy" 2012, no. 3.

Shonberg S., Legitimate expectation in administrative law, Oxford 2000.

Świątkiewicz J., Europejski Kodeks Dobrej Administracji (wprowadzenie, tekst i komentarz o zastosowaniu kodeksu $\mathrm{w}$ warunkach polskich procedur administracyjnych), Warszawa, March 2007.

Świątkiewicz J., Europejski Kodeks Dobrej Administracji (wprowadzenie, tekst i komentarz o zastosowaniu kodeksu w warunkach polskich procedur administracyjnych) Wydanie VI, Warszawa 2007, https://www.rpo.gov.pl/pliki/1192700305.pdf (access 30.11.2017).

Sharpston E., European Community Law and the Doctrine of Legitimate Expectations: How Legitimate, and for Whom, "Northwestern Journal of International Law \& Business" 1990, vol. 11, issue 1.

Thomas R., Legitimate expectation and proportionality, Oxford-Portland Oregon 2000.

Tuleja P., Komentarz do art. 2 Konstytucji, (in:) Konstytucja RP, tom 1, Komentarz do art. 1-86, M. Safjan, L. Bosek (eds.), Wraszawa 2016.

Zoll A., Prawo do dobrej administracji, (in:) Europejski kodeks Dobrej Administracji (tekst i komentarz o zastosowaniu kodeksu w warunkach polskich procedur administracyjnych), J. Świątkiewicz (ed.), Warszawa 2007, https://www.rpo.gov.pl/pliki/1192700305.pdf (access 8.12.2017). 